\title{
Behavioral and physiological responses of different genetic lines of free-range broiler raised on a semi-intensive system
}

\author{
Sicília Avelar Gonçalves • Rony Antonio Ferreira - Idalmo Garcia Pereira • \\ Caroline Carvalho de Oliveira - Pedro Ivo Sodré Amaral • \\ Cesar Augusto Pospissil Garbossa • Leonardo da Silva Fonseca
}

\section{SA Gonçalves - CC Oliveira}

Universidade Federal dos Vales do Jequitinhonha e Mucuri (UFVJM), 39100-000, Diamantina, MG, Brazil.

\section{RA Ferreira - PIS Amaral}

Universidade Federal de Lavras (UFLA), 37200-000, Lavras, MG, Brazil.

\section{IG Pereira}

Universidade Federal de Minas Gerais (UFMG), 30123-970, Belo Horizonte, MG, Brazil.

\section{CAP Garbossa}

Universidade Federal Rural da Amazônia (UFRA), 68625970, Paragominas, PA, Brazil.

LS Fonseca (Corresponding autor)

Universidade José do Rosário Vellano (UNIFENAS), 37132304, Alfenas, MG, Brazil.

e-mail: leofonseca29.1sf@gmail.com

Received: June 08, 2017 - Revised: August 17, 2017 - Accepted: August 18, 2017

\begin{abstract}
The aim of the study was evaluate the ability of adaptation of seven different genetic lines of free-range broilers to a semi-intensive raising system. Four hundred and twenty chicks of the Pescoço Pelado (PP), Carijó (CG), Colorpak (CPK), Tricolor (TRC), Caboclo (CBC), Gigante Negro (GNG) and Pesadão Vermelho (PS) genetic groups were used. At 28 days of age the birds were allowed access the paddocks and after three days of adaptation the monitoring of the animals has started, being performed behavioral visual observations from 07:00 to 17:00. Cloacal temperature (CT) and respiratory rate $(\mathrm{RR})$ were collected once a week. The environment was monitored considering the temperature, relative humidity and black globe temperature at various points of the paddocks and the shed. The physiological variables were evaluated using a randomized complete block design with a split plot arrangement. Behavioral variables were analyzed using nonparametric Friedman test. Birds of Carijó and Colorpak genetic line presented greater RR, 34.6 $\mathrm{mov} / \mathrm{min}$ and $36.0 \mathrm{mov} / \mathrm{min}$ respectively, compared to the birds of the Caboclo and Gigante Negro genetic line, 29.0 $\mathrm{mov} / \mathrm{min}$ and $28.4 \mathrm{mov} / \mathrm{min}$ respectively. The average values of RR and CT for all genetic lines were higher in the afternoon. At 7:00 and 17:00 the foraging behavior was more intense. The Caboclo and Gigante Negro genetic line were those that stood out in the behavior of foraging, consequently, they are more able to adapt to the semi-intensive raising system.
\end{abstract}

Keywords: ambience, animal welfare, poultry
The production of free-range poultry is growing and gaining importance worldwide, no longer being an activity of only small producers. This type of broiler has its own sensory characteristics, as a darker and firm flesh, sharp flavor and less fat content in carcass, differentiating from the birds raised in confinement (Takahashi 2006).

The semi-intensive raising system of free-range poultry has a different concept of industrial production being a less aggressive production considering the environment and birds. The animal health and welfare are positively affected by increasing the housing area per bird and for ensuring greater freedom of movement, which according to Sundrum (2001), brings carcasses with less fat and different texture and flavor.

Livestock animals have specific behavioral needs and are able to change their behavior to adapt to the environment. Among the climatic variables, high ambient temperature, humidity and direct sunlight are primarily responsible for causing the physiological discomfort that takes the animals to adopt physiological and behavioral actions to maintain homeothermy, and most of the times culminate with the decrease in productive performance (Souza 2010).

Study the behavior of these animals is as important as researching nutritional requirements or temperature thermal comfort because through behavior it is possible identify which genetic line are best appropriate to each raising system. The objective was to evaluate the ability to adapt to the semiintensive raising system of seven commercial free-range broiler genetic lines through behavioral and physiological parameters.

\section{Materials and Methods}


Local and animal care

The trial was conducted in the poultry facilities of the Federal University of Jequitinhonha and Mucuri Valleys, located in the city of Diamantina/MG, situated at 1,370 meters above sea level. The project was approved by the Ethic Committee on Animal Use of the Federal University of Jequitinhonha and Mucuri Valley by Protocol 015/10.

Animals, diet and experimental design

Sixty birds of each genetic line, totaling 420 males one day-old chicks from the following genetic lines: Pescoço Pelado (PP), Carijó (CG), Colorpak (CPK), Tricolor (TRC), Caboclo (CBC), Gigante Negro (GNG) and Pesadão Vermelho (PS) were used. The birds were weighed and evenly distributed according to similar weight in 14 experimental boxes with 7.5 birds $/ \mathrm{m}^{2}$ of stocking density. The experimental unit consisted of 30 birds in each box with a paddock.

After birth, all the birds were identified and vaccinated against fowlpox and Marek and then housed in boxes of 2.00 x $2.00 \mathrm{~m}$ in a poultry barn with eave height of $2.50 \mathrm{~m}, 6.00 \mathrm{~m}$ wide and $36.00 \mathrm{~m}$ long. After the 28th day of age, the birds of each box were allowed to access the respective paddock formed by a forage of Cynodon genus with $30 \mathrm{~m}^{2}$ of area. The evaluation of the animals started on the 31 st day and lasted until the 84th day of age. Behavioral visual observations were performed from 07:00 to 17:00 hours.

The feeds were formulated to meet the nutritional needs suggested by Rostagno et al (2005), being provided ad libitum, 24 hours a day, up to 70 days of age, after this period, it were provided ad libitum from 09:00 to 16:00 h. The animals received water ad libitum throughout the experimental period.

Assessment of welfare and environment

The observations of the animals were made from Monday to Friday at 07:00, 09:00, 11:00, 13:00, 15:00, and 17:00 h, recording the behavior in a behavioral sheet for two minutes per box. The observation was first made inside the box. Then the animals that were on the paddock were observed trough the fence of the box at the side to avoid interference of the observer.

The ethogram prepared for behavioral observations was based on studies of several authors: Rudkin and Stewart (2003), Alves et al (2004), Barbosa Filho et al (2007), Mollenhorst et al (2005) and Nazareno et al (2011) (Table 1). The number of animals inside the box and on the paddock was recorded for subsequent analysis of animal preference.

To the evaluation of the physiological parameters of cloacal temperature and respiratory rate five birds per box once a week were randomly selected at 09:00 and 15:00 h.

The environmental monitoring was performed by collecting dry bulb temperature, relative humidity and black globe temperature using thermometers installed at various points of the paddocks and at the barn. The variables were collected four times a day $(8: 00,10: 00,14: 00$ and 16:00 h) and these were used to calculate the black globe-humidity index (BGHI) according to Buffington et al (1981).

Table 1 Behavioral ethogram prepared for broilers.

\begin{tabular}{|c|c|}
\hline Behavior & Description \\
\hline Sitting & $\begin{array}{l}\text { Characterized by Behavior When the body of the bird is in contact with the ground, floor, or } \\
\text { bedding }\end{array}$ \\
\hline Eating & Consuming or pecking feed at the feeder \\
\hline Drinking & Consuming water at the drinker \\
\hline Foraging & Consuming or pecking the vegetal substrate in the paddock area \\
\hline Preening & Exploring the feathering with beak for both maintenance as investigation \\
\hline Non aggressive pecking & $\begin{array}{l}\text { Light pecking other birds, usually in the lower ventral region of the neck, back, base and tip of } \\
\text { the tail or abdomen }\end{array}$ \\
\hline Aggressive pecking & $\begin{array}{l}\text { Strong pecking another bird triggering aggressive or defensive reaction, usually directed to the } \\
\text { upper region of the head and comb or in the dorsal lower region of the neck }\end{array}$ \\
\hline Discomfort movements & $\begin{array}{l}\text { Movements to stretch the wings and legs on the same side of the body simultaneously, shaking } \\
\text { and whirring feathers, lifting part of both wings close to the body or extend the tips of the wings } \\
\text { and/or flapping it }\end{array}$ \\
\hline Scratching the ground & The bird explores his territory with his feet and beak, directed to the floor \\
\hline Dust bathing & $\begin{array}{l}\text { Revolving in the bedding substrate or on the soil in the paddock area, spreading it throughout } \\
\text { the body }\end{array}$ \\
\hline
\end{tabular}


Statistical analysis

The physiological variables were tested for normality by the Shapiro-Wilk test before analysis, and any variable that failed to follow normal distribution was transformed through the RANK procedure of SAS (SAS Inst. Inc., Cary, NC) (SAS Institute, 2003). The PROC RANK statement with the NORMAL option was used to produce a normalized transformed variable. After normalization the data were evaluated using a randomized complete block design with a split plot design by the MIXED procedure of SAS. The seven genetic lines were considered as plots, the period of the day (morning / afternoon) the subplot factor and collection days as a block (repetitions), the data were submitted to variance analysis and the least squares means were compared using the Tukey test with $\mathrm{P}<0.05$. The behavioral variables were analyzed by SAS using FREQ procedure and compared trough nonparametric Friedman test, $\mathrm{P}<0.05$ being considered significant (SAS Institute, 2003).

\section{Results and Discussion}

During the trial period, inside of the barn, the average air temperature remained at 21.5 and the average relative humidity of $74.6 \%$. In paddock the average temperature remained at $23.2{ }^{\circ} \mathrm{C}$ and the average humidity in $64.7 \%$. The location of the facility, with a good natural air circulation contributed to the occurrence of mild average temperatures during the trial period. The temperature and humidity are in accordance with Tinôco (2001), which found that air temperatures between $15{ }^{\circ} \mathrm{C}$ to $25{ }^{\circ} \mathrm{C}$ and relative humidity between 50 to $70 \%$ are suitable for adult birds allowing them to meet environment comfortable for most of the day.

Analyzing the results of BGHI (Figure 1) it can be observed that there was an increase in this index from 8:00 to 14:00 h, reaching 74.5, decreasing after this time. The period between 10:00 and 16:00 $\mathrm{h}$ was the one that presented the highest BGHI values, due to the higher incidence of the sun at these times. At none period BGHI was above the acceptable level of comfort that is 77 for broilers (Furtado, 2014).

The birds from the genetic line Colorpak presented greater RR $(\mathrm{P}<0.05)$ compared with birds from the Caboclo genetic line. The birds of the others genetic lines presented intermediary RR (Table 2). These results allow us to infer that birds of Caboclo line may have been more effective at dissipating body heat because they have lower final body weight as shown by Veloso et al (2014) and thus producing less heat, facilitating thermolysis. This can be explained by the greater ease that animals with lower body mass present to dissipate heat in relation to those of greater mass.

The cloacal temperature were greater $(\mathrm{P}<0.05)$ for Carijó genetic line compared to Colorpak, probably Colorpak line had a lower temperature because these birds had a greater respiratory rate, in this way allowing the animals to lower their body temperature, for all the other genetic lines the temperature did not differed.

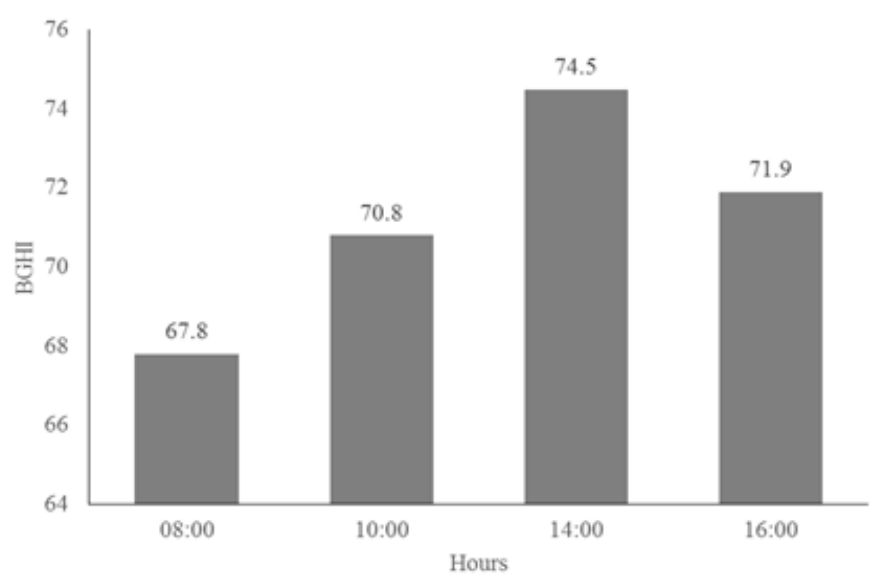

Figure 1 Calculated values of BGHI according to the hours of the day.

Analyzing the average values of RR and CT for all genetic lines in the morning and afternoon, was found that both variables had greater values in the afternoon $(\mathrm{P}<0.05)$, because the environment has presented greater BGHI at this period, causing a lesser comfort condition for the birds.

During afternoon, the environmental temperature is greater and the birds need to resort to some mechanism to keep the body temperature stable. At the beginning, the respiratory rate is increased and if this thermolysis mechanism is not enough to dissipate the extra body heat the cloacal temperature is raised. Thus, the Caboclo and Gigante Negro genetic lines were more adapted to the environment by keeping the respiratory rate at normal levels.

The results corroborate those found by Macari and Furlan (2004) who said that the cloacal temperature of the birds is affected by the time of day, the birds had lower cloacal temperature in the morning (before sunrise) when compared to the afternoon.

For the behavior of eating, drinking, preening, nonaggressive pecking, aggressive pecking, discomfort movements, scratching the ground, and dust bathing there is none effect $(\mathrm{P}>0.05)$ of the genetic line at 07:00 h (Table 3), and the Caboclo and Gigante Negro genetic lines were the ones that had the lowest behaviors of sitting and foraging at this period.

For all genetic lines from 09:00 h, there was a reduction in foraging behavior and increase in sitting behavior. Eating behavior was increased at 09:00 $\mathrm{h}$ compared to 07:00 $\mathrm{h}$ and as a result, drinking behavior increased for all genetic lines. However, Caboclo and Gigante Negro genetic lines continued with the greater behavior of foraging. 
Table 2 Results for respiratory rate (RR) and cloacal temperature (CT) in the morning and afternoon periods obtained in broilers of different genetic lines raised in a semi-intesive system.

\begin{tabular}{|c|c|c|c|c|c|c|c|c|}
\hline \multirow{2}{*}{ Genetic } & \multicolumn{2}{|c|}{$\mathrm{RR}$ (mov/min) } & \multirow{2}{*}{ Mean } & \multirow{2}{*}{ SEM } & \multicolumn{2}{|c|}{$\mathrm{CT}\left({ }^{\circ} \mathrm{C}\right)$} & \multirow{2}{*}{ Mean } & \multirow{2}{*}{ SEM } \\
\hline & Morning & Afternoon & & & Morning & Afternoon & & \\
\hline Caboclo & 24.40 & 33.60 & $29.00^{\mathrm{b}}$ & 2.64 & 41.41 & $41.56^{\mathrm{ab}}$ & 41.49 & 0.0595 \\
\hline Carijó & 29.20 & 40.00 & $34.60^{\mathrm{ab}}$ & 2.64 & 41.46 & $41.63^{\mathrm{a}}$ & 41.55 & 0.0595 \\
\hline Colorpak & 30.80 & 41.20 & $36.00^{\mathrm{a}}$ & 2.64 & 41.34 & $41.49^{\mathrm{b}}$ & 41.42 & 0.0595 \\
\hline Gigante Negro & 26.80 & 30.00 & $28.40^{\mathrm{ab}}$ & 2.64 & 41.49 & $41.63^{\mathrm{ab}}$ & 41.56 & 0.0595 \\
\hline Pescoço Pelado & 30.00 & 33.20 & $31.60^{\mathrm{ab}}$ & 2.64 & 41.50 & $41.55^{\mathrm{ab}}$ & 41.52 & 0.0595 \\
\hline Pesadão Vermelho & 27.81 & 36.00 & $31.91^{\mathrm{ab}}$ & 2.64 & 41.39 & $41.57^{\mathrm{ab}}$ & 41.48 & 0.0595 \\
\hline Tricolor & 27.60 & 38.00 & $32.80^{\mathrm{ab}}$ & 2.64 & 41.35 & $41.49^{\mathrm{ab}}$ & 41.42 & 0.0595 \\
\hline Mean & $28.09^{\mathrm{B}}$ & $36.00^{\mathrm{A}}$ & & & $41.42^{\mathrm{B}}$ & $41.56^{\mathrm{A}}$ & & \\
\hline
\end{tabular}

Means followed by lowercase different letters in the column differ among themselves by Tukey test with 5\% of significance and means followed by uppercase different letters in the row differ among themselves by $\mathrm{T}$ test with $5 \%$ of significance.

Generally an increase in discomfort movement can be noticed between 11:00 and 15:00 $\mathrm{h}$. This behavior was more evident in genetic lines with higher body weight (Carijó, Colorpak, Pesadão Vermelho, and Tricolor) and, consequently, had shown greater sensitivity to higher temperatures. In this kind of environment (heat stress), birds change their behavior to maintain body temperature and to remain it within normal limits. Behavioral adjustments can occur quickly and at a lower cost than the physiological adjustments. As a consequence of greater discomfort presented in the aforementioned genetic lines it can be observed more birds preening, which probably would be indicative of discomfort.

In the afternoon, most of the animals of each genetic line remained sitting and had the others behaviors greatly reduced, motivated by the increased temperature. Such behavior contributes to heat exchange with the bedding, improving the thermal comfort.

From 15:00 h, the foraging behavior became more intense in all genetic lines. However, at 17:00 h, the birds of the Caboclo and Gigante Negro genetic lines were the greatest number of animals foraging $(\mathrm{P}<0.05)$.

At 07:00 and 17:00 h, the genetic lines that had more animals out of the barn were the Caboclo and Gigante Negro, but the vast majority preferred to remain inside the barn, corresponding to about $89 \%$ of the total (Table 4). The absence of shade or perch on the paddoc may have contributed to the animals avoid stay at the outside area. This hypothesis can be corroborated by the findings of Santos et al (2010), which observer greater rates of animals outside the barn when the area was enriched with perches and shading.

Table 3 Behavior of animals during daylight hours.

\begin{tabular}{|c|c|c|c|c|c|c|c|c|c|c|}
\hline & $\mathrm{S}$ & $\mathrm{E}$ & $\mathrm{D}$ & $\mathrm{F}$ & $\mathrm{P}$ & NAP & AP & $\mathrm{DM}$ & $\mathrm{SG}$ & DB \\
\hline Genetic line & \multicolumn{10}{|c|}{ 07:00 h } \\
\hline $\mathrm{CBC}$ & $10.42^{b}$ & $2.28^{\mathrm{a}}$ & $0.33^{\mathrm{a}}$ & $2.11^{\mathrm{a}}$ & $2.31^{\mathrm{a}}$ & $0.11^{\mathrm{a}}$ & $0.00^{\mathrm{a}}$ & $0.47^{\mathrm{a}}$ & $0.42^{\mathrm{a}}$ & $0.00^{\mathrm{a}}$ \\
\hline $\mathrm{CG}$ & $23.78^{a}$ & $3.03^{\mathrm{a}}$ & $0.44^{\mathrm{a}}$ & $0.61^{b}$ & $3.28^{\mathrm{a}}$ & $0.06^{\mathrm{a}}$ & $0.11^{\mathrm{a}}$ & $0.81^{\mathrm{a}}$ & $0.00^{\mathrm{a}}$ & $0.00^{\mathrm{a}}$ \\
\hline $\mathrm{CPK}$ & $22.50^{\mathrm{a}}$ & $2.36^{\mathrm{a}}$ & $0.44^{\mathrm{a}}$ & $0.89^{\mathrm{a}}$ & $2.83^{\mathrm{a}}$ & $0.06^{\mathrm{a}}$ & $0.06^{\mathrm{a}}$ & $0.78^{\mathrm{a}}$ & $0.06^{\mathrm{a}}$ & $0.00^{\mathrm{a}}$ \\
\hline GNG & $10.22^{b}$ & $2.42^{\mathrm{a}}$ & $0.39^{\mathrm{a}}$ & $2.69^{\mathrm{a}}$ & $1.97^{\mathrm{a}}$ & $0.06^{\mathrm{a}}$ & $0.11^{\mathrm{a}}$ & $0.42^{\mathrm{a}}$ & $0.33^{\mathrm{a}}$ & $0.89^{\mathrm{a}}$ \\
\hline PP & $19.36^{\mathrm{a}}$ & $3.06^{\mathrm{a}}$ & $0.42^{\mathrm{a}}$ & $1.19^{\mathrm{ab}}$ & $2.86^{\mathrm{a}}$ & $0.06^{\mathrm{a}}$ & $0.31^{\mathrm{a}}$ & $0.64^{\mathrm{a}}$ & $0.19^{\mathrm{a}}$ & $0.03^{\mathrm{a}}$ \\
\hline PS & $21.64^{\mathrm{a}}$ & $3.44^{\mathrm{a}}$ & $0.86^{\mathrm{a}}$ & $0.89^{a b}$ & $2.36^{\mathrm{a}}$ & $0.08^{\mathrm{a}}$ & $0.19^{\mathrm{a}}$ & $0.81^{\mathrm{a}}$ & $0.00^{\mathrm{a}}$ & $0.00^{\mathrm{a}}$ \\
\hline \multirow[t]{2}{*}{ TRC } & $22.75^{\mathrm{a}}$ & $2.86^{\mathrm{a}}$ & $0.39^{\mathrm{a}}$ & $1.31^{\mathrm{ab}}$ & $3.47^{\mathrm{a}}$ & $0.11^{\mathrm{a}}$ & $0.11^{\mathrm{a}}$ & $0.78^{\mathrm{a}}$ & $0.00^{\mathrm{a}}$ & $0.00^{\mathrm{a}}$ \\
\hline & \multicolumn{10}{|c|}{ 09:00 h } \\
\hline $\mathrm{CBC}$ & $12.22^{b}$ & $4.78^{b}$ & $0.36^{\mathrm{b}}$ & $1.92^{\mathrm{a}}$ & $2.06^{\mathrm{a}}$ & $0.03^{\mathrm{a}}$ & $0.06^{\mathrm{a}}$ & $0.75^{a}$ & $0.19^{\mathrm{a}}$ & $0.00^{\mathrm{a}}$ \\
\hline $\mathrm{CG}$ & $24.47^{\mathrm{a}}$ & $5.72^{\mathrm{ab}}$ & $0.81^{\mathrm{ab}}$ & $0.22^{\mathrm{ab}}$ & $2.28^{\mathrm{a}}$ & $0.08^{\mathrm{a}}$ & $0.03^{\mathrm{a}}$ & $0.64^{\mathrm{a}}$ & $0.00^{\mathrm{a}}$ & $0.00^{\mathrm{a}}$ \\
\hline $\mathrm{CPK}$ & $21.53^{\mathrm{a}}$ & $6.36^{\mathrm{ab}}$ & $0.83^{\mathrm{ab}}$ & $0.39^{a}$ & $2.53^{\mathrm{a}}$ & $0.25^{\mathrm{a}}$ & $0.11^{\mathrm{a}}$ & $0.69^{\mathrm{a}}$ & $0.00^{\mathrm{a}}$ & $0.00^{\mathrm{a}}$ \\
\hline GNG & $12.56^{b}$ & $5.50^{\mathrm{ab}}$ & $0.69^{\mathrm{ab}}$ & $1.03^{\mathrm{a}}$ & $2.31^{\mathrm{a}}$ & $0.03^{\mathrm{a}}$ & $0.00^{\mathrm{a}}$ & $0.42^{\mathrm{a}}$ & $0.06^{\mathrm{a}}$ & $0.03^{\mathrm{a}}$ \\
\hline PP & $20.36^{\mathrm{a}}$ & $7.36^{\mathrm{a}}$ & $1.28^{\mathrm{a}}$ & $0.17^{b}$ & $1.94^{\mathrm{a}}$ & $0.17^{\mathrm{a}}$ & $0.06^{\mathrm{a}}$ & $0.75^{\mathrm{a}}$ & $0.06^{\mathrm{a}}$ & $0.03^{\mathrm{a}}$ \\
\hline PS & $20.83^{\mathrm{a}}$ & $6.28^{\mathrm{ab}}$ & $0.92^{\mathrm{ab}}$ & $0.17^{b}$ & $2.83^{\mathrm{a}}$ & $0.17^{\mathrm{a}}$ & $0.14^{\mathrm{a}}$ & $0.42^{\mathrm{a}}$ & $0.00^{\mathrm{a}}$ & $0.06^{\mathrm{a}}$ \\
\hline \multirow[t]{2}{*}{ TRC } & $23.89^{a}$ & $5.44^{\mathrm{ab}}$ & $0.89^{a b}$ & $0.36^{\mathrm{a}}$ & $2.72^{\mathrm{a}}$ & $0.06^{\mathrm{a}}$ & $0.00^{\mathrm{a}}$ & $0.75^{\mathrm{a}}$ & $0.03^{\mathrm{a}}$ & $0.03^{\mathrm{a}}$ \\
\hline & \multicolumn{10}{|c|}{$11: 00 \mathrm{~h}$} \\
\hline
\end{tabular}




\begin{tabular}{|c|c|c|c|c|c|c|c|c|c|c|}
\hline $\mathrm{CBC}$ & $14.85^{b}$ & $3.76^{b}$ & $0.85^{\mathrm{a}}$ & $1.03^{\mathrm{a}}$ & $2.29^{\mathrm{a}}$ & $0.06^{\mathrm{a}}$ & $0.00^{\mathrm{a}}$ & $0.71^{\mathrm{a}}$ & $0.09^{\mathrm{a}}$ & $0.00^{\mathrm{a}}$ \\
\hline $\mathrm{CG}$ & $23.91^{\mathrm{a}}$ & $4.53^{\mathrm{ab}}$ & $0.91^{\mathrm{a}}$ & $0.12^{\mathrm{a}}$ & $2.03^{\mathrm{a}}$ & $0.09^{\mathrm{a}}$ & $0.00^{\mathrm{a}}$ & $0.79^{\mathrm{a}}$ & $0.00^{\mathrm{a}}$ & $0.03^{\mathrm{a}}$ \\
\hline CPK & $23.85^{\mathrm{a}}$ & $4.62^{\mathrm{ab}}$ & $1.03^{\mathrm{a}}$ & $0.12^{\mathrm{a}}$ & $2.73^{\mathrm{a}}$ & $0.15^{\mathrm{a}}$ & $0.03^{\mathrm{a}}$ & $1.26^{\mathrm{a}}$ & $0.03^{\mathrm{a}}$ & $0.03^{\mathrm{a}}$ \\
\hline GNG & $14.12^{b}$ & $4.32^{\mathrm{ab}}$ & $0.91^{\mathrm{a}}$ & $0.47^{\mathrm{a}}$ & $2.32^{\mathrm{a}}$ & $0.00^{\mathrm{a}}$ & $0.03^{\mathrm{a}}$ & $0.59^{b}$ & $0.12^{\mathrm{a}}$ & $0.03^{\mathrm{a}}$ \\
\hline PP & $22.73^{a}$ & $6.71^{a}$ & $1.32^{\mathrm{a}}$ & $0.06^{\mathrm{a}}$ & $2.23^{\mathrm{a}}$ & $0.29^{\mathrm{a}}$ & $0.09^{\mathrm{a}}$ & $1.29^{\mathrm{a}}$ & $0.03^{\mathrm{a}}$ & $0.21^{\mathrm{a}}$ \\
\hline PS & $22.73^{\mathrm{a}}$ & $6.26^{\mathrm{ab}}$ & $1.15^{\mathrm{a}}$ & $0.00^{\mathrm{b}}$ & $3.00^{\mathrm{a}}$ & $0.18^{\mathrm{a}}$ & $0.00^{\mathrm{a}}$ & $1.00^{\mathrm{a}}$ & $0.00^{\mathrm{a}}$ & $0.00^{\mathrm{a}}$ \\
\hline TRC & $24.50^{\mathrm{a}}$ & $4.59^{\mathrm{ab}}$ & $1.44^{\mathrm{a}}$ & $0.12^{\mathrm{a}}$ & $2.94^{\mathrm{a}}$ & $0.12^{\mathrm{a}}$ & $0.00^{\mathrm{a}}$ & $1.38^{\mathrm{a}}$ & $0.00^{\mathrm{a}}$ & $0.09^{\mathrm{a}}$ \\
\hline & \multicolumn{10}{|c|}{$13: 00 \mathrm{~h}$} \\
\hline $\mathrm{CBC}$ & $14.85^{\mathrm{b}}$ & $3.71^{\mathrm{a}}$ & $0.88^{a}$ & $0.91^{\mathrm{a}}$ & $1.73^{\mathrm{b}}$ & $0.03^{\mathrm{a}}$ & $0.03^{\mathrm{a}}$ & $1.23^{\mathrm{ab}}$ & $0.23^{\mathrm{a}}$ & $0.82^{\mathrm{a}}$ \\
\hline $\mathrm{CG}$ & $25.71^{\mathrm{a}}$ & $4.23^{\mathrm{a}}$ & $1.21^{\mathrm{a}}$ & $0.15^{\mathrm{a}}$ & $3.18^{\mathrm{a}}$ & $0.23^{\mathrm{a}}$ & $0.09^{\mathrm{a}}$ & $1.59^{\mathrm{a}}$ & $0.03^{\mathrm{a}}$ & $0.35^{\mathrm{a}}$ \\
\hline CPK & $25.18^{\mathrm{a}}$ & $4.47^{\mathrm{a}}$ & $0.94^{\mathrm{a}}$ & $0.15^{\mathrm{a}}$ & $1.91^{\mathrm{a}}$ & $0.12^{\mathrm{a}}$ & $0.06^{\mathrm{a}}$ & $1.59^{\mathrm{a}}$ & $0.03^{\mathrm{a}}$ & $0.44^{\mathrm{a}}$ \\
\hline GNG & $15.03^{\mathrm{b}}$ & $4.15^{\mathrm{a}}$ & $0.65^{\mathrm{a}}$ & $0.29^{a}$ & $1.73^{b}$ & $0.06^{\mathrm{a}}$ & $0.06^{\mathrm{a}}$ & $0.56^{\mathrm{b}}$ & $0.06^{\mathrm{a}}$ & $0.29^{\mathrm{a}}$ \\
\hline PP & $23.12^{\mathrm{ab}}$ & $5.68^{\mathrm{a}}$ & $0.91^{\mathrm{a}}$ & $0.23^{\mathrm{a}}$ & $2.00^{\mathrm{a}}$ & $0.12^{\mathrm{a}}$ & $0.00^{\mathrm{a}}$ & $1.23^{\mathrm{ab}}$ & $0.12^{\mathrm{a}}$ & $0.68^{\mathrm{a}}$ \\
\hline PS & $25.73^{\mathrm{a}}$ & $4.62^{\mathrm{a}}$ & $1.35^{\mathrm{a}}$ & $0.12^{\mathrm{a}}$ & $2.59^{\mathrm{a}}$ & $0.12^{\mathrm{a}}$ & $0.06^{\mathrm{a}}$ & $1.59^{\mathrm{a}}$ & $0.00^{\mathrm{a}}$ & $0.41^{\mathrm{a}}$ \\
\hline \multirow[t]{2}{*}{ TRC } & $25.54^{\mathrm{a}}$ & $4.40^{\mathrm{a}}$ & $1.09^{\mathrm{a}}$ & $0.32^{\mathrm{a}}$ & $2.79^{\mathrm{a}}$ & $0.00^{\mathrm{a}}$ & $0.00^{\mathrm{a}}$ & $1.41^{\mathrm{a}}$ & $0.00^{\mathrm{a}}$ & $0.50^{\mathrm{a}}$ \\
\hline & \multicolumn{10}{|c|}{$15: 00 \mathrm{~h}$} \\
\hline $\mathrm{CBC}$ & $10.75^{b}$ & $4.22^{\mathrm{a}}$ & $1.34^{\mathrm{a}}$ & $3.00^{\mathrm{a}}$ & $1.66^{\mathrm{a}}$ & $0.06^{\mathrm{a}}$ & $0.03^{a}$ & $0.66^{\mathrm{a}}$ & $0.12^{\mathrm{a}}$ & $0.03^{a}$ \\
\hline $\mathrm{CG}$ & $26.72^{a}$ & $4.59^{\mathrm{a}}$ & $1.03^{\mathrm{a}}$ & $0.22^{\mathrm{b}}$ & $2.31^{\mathrm{a}}$ & $0.19^{\mathrm{a}}$ & $0.06^{\mathrm{a}}$ & $1.16^{\mathrm{ab}}$ & $0.00^{\mathrm{a}}$ & $0.22^{\mathrm{a}}$ \\
\hline CPK & $24.44^{\mathrm{a}}$ & $4.69^{a}$ & $1.00 \mathrm{a}$ & $0.34^{\mathrm{ab}}$ & $2.44^{\mathrm{a}}$ & $0.09^{\mathrm{a}}$ & $0.09^{\mathrm{a}}$ & $1.37^{\mathrm{ab}}$ & $0.00^{\mathrm{a}}$ & $0.16^{\mathrm{a}}$ \\
\hline GNG & $15.34^{\mathrm{a}}$ & $4.65^{\mathrm{a}}$ & $0.87^{\mathrm{a}}$ & $0.97^{\mathrm{ab}}$ & $1.72^{\mathrm{a}}$ & $0.06^{\mathrm{a}}$ & $0.06^{\mathrm{a}}$ & $0.56^{\mathrm{b}}$ & $0.06^{\mathrm{a}}$ & $0.12^{\mathrm{a}}$ \\
\hline PP & $22.72^{\mathrm{ab}}$ & $5.37^{\mathrm{a}}$ & $1.25^{\mathrm{a}}$ & $0.37^{\mathrm{ab}}$ & $2.84^{\mathrm{a}}$ & $0.06^{\mathrm{a}}$ & $0.16^{\mathrm{a}}$ & $1.59^{\mathrm{ab}}$ & $0.12^{\mathrm{a}}$ & $0.34^{\mathrm{a}}$ \\
\hline PS & $22.53^{\mathrm{ab}}$ & $4.84^{\mathrm{a}}$ & $0.91^{\mathrm{a}}$ & $0.00^{\mathrm{b}}$ & $3.00^{\mathrm{a}}$ & $0.03^{\mathrm{a}}$ & $0.03^{\mathrm{a}}$ & $1.22^{\mathrm{ab}}$ & $0.00^{\mathrm{a}}$ & $0.37^{\mathrm{a}}$ \\
\hline \multirow[t]{2}{*}{ TRC } & $24.16^{\mathrm{a}}$ & $4.28^{\mathrm{a}}$ & $1.16^{\mathrm{a}}$ & $0.75^{\mathrm{ab}}$ & $2.84^{\mathrm{a}}$ & $0.12^{\mathrm{a}}$ & $0.03^{\mathrm{a}}$ & $1.97^{\mathrm{a}}$ & $0.00^{\mathrm{a}}$ & $0.50^{\mathrm{a}}$ \\
\hline & \multicolumn{10}{|c|}{$17: 00 \mathrm{~h}$} \\
\hline $\mathrm{CBC}$ & $8.26^{\mathrm{b}}$ & $2.68^{a}$ & $0.62^{\mathrm{a}}$ & $4.73^{\mathrm{a}}$ & $1.32^{\mathrm{a}}$ & $0.03^{a}$ & $0.03^{a}$ & $0.73^{\mathrm{a}}$ & $0.41^{a}$ & $0.12^{\mathrm{a}}$ \\
\hline $\mathrm{CG}$ & $25.53^{\mathrm{a}}$ & $3.65^{\mathrm{a}}$ & $0.73^{\mathrm{a}}$ & $0.38^{\mathrm{b}}$ & $2.38^{\mathrm{a}}$ & $0.03^{\mathrm{a}}$ & $0.03^{\mathrm{a}}$ & $1.12^{\mathrm{a}}$ & $0.03^{\mathrm{a}}$ & $0.15^{\mathrm{a}}$ \\
\hline $\mathrm{CPK}$ & $22.23^{\mathrm{a}}$ & $4.32^{\mathrm{a}}$ & $0.88^{\mathrm{a}}$ & $0.23^{b}$ & $2.00^{\mathrm{a}}$ & $0.12^{\mathrm{a}}$ & $0.09^{\mathrm{a}}$ & $0.94^{\mathrm{a}}$ & $0.18^{a}$ & $0.18^{\mathrm{a}}$ \\
\hline GNG & $10.88^{b}$ & $3.21^{\mathrm{a}}$ & $0.65^{\mathrm{a}}$ & $2.12^{\mathrm{a}}$ & $1.29^{\mathrm{a}}$ & $0.06^{\mathrm{a}}$ & $0.00^{\mathrm{a}}$ & $0.41^{\mathrm{a}}$ & $0.32^{\mathrm{a}}$ & $0.03^{\mathrm{a}}$ \\
\hline PP & $20.29^{a b}$ & $4.79^{a}$ & $1.12^{\mathrm{a}}$ & $0.82^{\mathrm{ab}}$ & $2.12^{\mathrm{a}}$ & $0.09^{\mathrm{a}}$ & $0.06^{\mathrm{a}}$ & $0.82^{\mathrm{a}}$ & $0.06^{\mathrm{a}}$ & $0.12^{\mathrm{a}}$ \\
\hline PS & $23.71^{\mathrm{a}}$ & $4.35^{\mathrm{a}}$ & $0.73^{\mathrm{a}}$ & $0.12^{\mathrm{b}}$ & $2.44^{\mathrm{a}}$ & $0.09^{\mathrm{a}}$ & $0.09^{\mathrm{a}}$ & $0.88^{a}$ & $0.00^{\mathrm{a}}$ & $0.23^{\mathrm{a}}$ \\
\hline TRC & $23.29^{\mathrm{a}}$ & $4.03^{\mathrm{a}}$ & $1.29^{\mathrm{a}}$ & $0.73^{\mathrm{ab}}$ & $2.53^{\mathrm{a}}$ & $0.06^{\mathrm{a}}$ & $0.03^{\mathrm{a}}$ & $0.79^{\mathrm{a}}$ & $0.15^{\mathrm{a}}$ & $0.21^{\mathrm{a}}$ \\
\hline
\end{tabular}

Means followed by different letters in the column differ among themselves by Friedman test at 5\% of significance. CBC: Caboclo; CG: Carijó; CPK: Colorpak; GNG: Gigante Negro; PP: Pescoço Pelado; PS: Pesadão Vermelho TRC: Tricolor. S: Sitting; E: Eating; D: Drinking; F: Foraging P: Preening; NAP: Non aggressive pecking; AP: Aggressive pecking; DM: Discomfort movements; SG: Scratching the ground; DB: Dust bathing.

Table 4 Percentage of birds each line inside (I) and outside (O) of the barn at each observation time and average percentage of animals inside (I) and outside $(\mathrm{O})$ of the barn for the observed times.

\begin{tabular}{|c|c|c|c|c|c|c|c|c|c|c|c|c|}
\hline \multirow{3}{*}{$\begin{array}{l}\text { Genetic } \\
\text { line }\end{array}$} & \multicolumn{12}{|c|}{ Time of the day } \\
\hline & \multicolumn{2}{|c|}{$7: 00 \mathrm{~h}$} & \multicolumn{2}{|c|}{$9: 00 \mathrm{~h}$} & \multicolumn{2}{|c|}{$11: 00 \mathrm{~h}$} & \multicolumn{2}{|c|}{$13: 00 \mathrm{~h}$} & \multicolumn{2}{|c|}{$15: 00 \mathrm{~h}$} & \multicolumn{2}{|c|}{$17: 00 \mathrm{~h}$} \\
\hline & $\% \mathrm{I}$ & $\% \mathrm{O}$ & $\% \mathrm{I}$ & $\% \mathrm{O}$ & $\% \mathrm{I}$ & $\% \mathrm{O}$ & $\% \mathrm{I}$ & $\% \mathrm{O}$ & $\% \mathrm{I}$ & $\% \mathrm{O}$ & $\% \mathrm{I}$ & $\% \mathrm{O}$ \\
\hline $\mathrm{CBC}$ & $69.4^{\mathrm{b}}$ & $30.6^{\mathrm{ab}}$ & $81.2^{\mathrm{b}}$ & $18.8^{\mathrm{a}}$ & $89.2^{\mathrm{b}}$ & $10.8^{\mathrm{a}}$ & $89.4^{\mathrm{b}}$ & $10.6^{\mathrm{a}}$ & $78.0^{\mathrm{b}}$ & $22.0^{\mathrm{a}}$ & $65.1^{\mathrm{b}}$ & $34.9^{\mathrm{a}}$ \\
\hline $\mathrm{CG}$ & $82.1^{\mathrm{a}}$ & $17.9^{\mathrm{b}}$ & $91.5^{\mathrm{a}}$ & $8.8^{\mathrm{ab}}$ & $93.4^{\mathrm{a}}$ & $6.6^{\mathrm{a}}$ & $97.9^{\mathrm{a}}$ & $2.1^{\mathrm{b}}$ & $96.4^{\mathrm{a}}$ & $3.6^{\mathrm{b}}$ & $94.8^{\mathrm{a}}$ & $5.2^{\mathrm{b}}$ \\
\hline CPK & $85.2^{\mathrm{a}}$ & $14.8^{\mathrm{b}}$ & $91.7^{\mathrm{a}}$ & $8.3^{\mathrm{ab}}$ & $94.5^{\mathrm{a}}$ & $5.5^{\mathrm{a}}$ & $98.6^{\mathrm{a}}$ & $1.4^{\mathrm{b}}$ & $94.8^{\mathrm{a}}$ & $5.2^{\mathrm{b}}$ & $95.1^{\mathrm{a}}$ & $4.9^{\mathrm{b}}$ \\
\hline GNG & $61.7^{\mathrm{b}}$ & $38.3^{\mathrm{a}}$ & $86.5^{\mathrm{a}}$ & $13.5^{\mathrm{ab}}$ & $94.9^{\mathrm{a}}$ & $5.1^{\mathrm{a}}$ & $97.7^{\mathrm{a}}$ & $2.3^{\mathrm{b}}$ & $98.4^{\mathrm{a}}$ & $1.6^{\mathrm{b}}$ & $80.9^{\mathrm{b}}$ & $19.1^{\mathrm{ab}}$ \\
\hline PP & $80.5^{\mathrm{a}}$ & $19.5^{\mathrm{b}}$ & $93.6^{\mathrm{a}}$ & $6.4^{\mathrm{b}}$ & $95.7^{\mathrm{a}}$ & $4.3^{\mathrm{a}}$ & $96.7^{\mathrm{a}}$ & $3.3^{\mathrm{b}}$ & $94.1^{\mathrm{a}}$ & $5.9^{\mathrm{b}}$ & $91.8^{\mathrm{a}}$ & $8.2^{\mathrm{b}}$ \\
\hline PS & $80.8^{a}$ & $19.2^{\mathrm{b}}$ & $88.3^{\mathrm{a}}$ & $11.7^{\mathrm{ab}}$ & $95.5^{\mathrm{a}}$ & $4.5^{\mathrm{a}}$ & $99.3^{\mathrm{a}}$ & $0.7^{\mathrm{b}}$ & $95.6^{\mathrm{a}}$ & $4.4^{\mathrm{b}}$ & $93.7^{\mathrm{a}}$ & $6.3^{\mathrm{b}}$ \\
\hline TRC & $70.1^{\mathrm{ab}}$ & $29.9^{\mathrm{ab}}$ & $86.3^{\mathrm{a}}$ & $13.7^{\mathrm{ab}}$ & $94.5^{\mathrm{a}}$ & $5.5^{\mathrm{a}}$ & $92.9^{\mathrm{a}}$ & $7.1^{\mathrm{a}}$ & $91.1^{\mathrm{ab}}$ & $8.9^{\mathrm{b}}$ & $90.6^{\mathrm{a}}$ & $9.4^{\mathrm{ab}}$ \\
\hline Mean & 75.7 & 24.3 & 88.4 & 11.6 & 94.0 & 6.0 & 96.1 & 3.9 & 92.6 & 7.4 & 87.4 & 12.6 \\
\hline
\end{tabular}

Means followed by different letters in the column differ by Friedman test at 5\% significance. CBC: Caboclo; CG: Carijó; CPK: Colorpak; GNG: Gigante Negro; PP: Pescoço Pelado; PS: Pesadão Vermelho TRC: Tricolor. 
Considering the genetic lines evaluated, the Caboclo genetic line showed greater preference to stay out of the barn. This may be indicative of greater adaptability to the raising system.

Veloso et al (2006), evaluating the same genetics lines of free-range broilers in a semi-intensive raising system found that the average daily feed intake (ADFI) was higher in Colorpak, Pesadão Vermelho and Pescoço Pelado. The Caboclo and Gigante Negro genetic lines when reached the weight of $2.300 \mathrm{~g}$ had the lowest values for ADFI showing that animals that graze more consume less feed.

\section{Conclusions}

The Caboclo e Gigante Negro genetic lines expressed more favorable behaviors for the semi-intensive raising system, being more active during most of the day and remained longer in the grazing area and less time sitting. Physiologically Caboclo were also more efficient controlling respiratory rate.

\section{Conflict of interest}

We certify that there is no conflict of interest with any financial organization regarding the material discussed in the manuscript.

\section{Acknowledgements}

To Globo aves, Avifran, Conselho Nacional de Desenvolvimento Científico e Tecnológico (CNPq), and Fundação de Amparo à Pesquisa do Estado de Minas Gerais (FAPEMIG) for financial support and supply of animals. In memory of Professor Aldrin Vieira Pires for contributions in writing the project, conducting the experiment and writing the article.

\section{References}

Alves SP, Barbosa Filho JAD, Silva MAN, Bernardi J (2004) Comparações entre comportamentos de aves poedeiras criadas no sistema de gaiolas e em cama. Revista Brasileira de Ciência Avícola 6:140.

Barbosa Filho JAD, Silva IJO, Silva MAN, Silva CJM (2007) Avaliação dos comportamentos de aves poedeiras utilizando sequência de imagens. Engenharia Agrícola 27:93.

Buffington DE, Collasso-Arocho A, Canton GH, Pitt D, Thatcher WW, Collier RJ (1981) Black globe humidity index (BGHI) as comfort equation for dairy cows. Transactions of the ASAE, St. Joseph 24:711-714.

Furtado DA, Azevedo PV, Tinôco IFF (2003) Análise do conforto térmico em galpões avícolas com diferentes sistemas de acondicionamento. Revista Brasileira de Engenharia Agrícola e Ambiental 7:559-564.
Nazareno AC, Pandorfi H, Guiselin C, Vigoderis RB, Pedrosa EMR (2011) Bem-estar na produção de frango de corte em diferentes sistemas de criação. Engenharia Agrícola 31:13-22.

Macari M, Furlan RL, Maiorka A (2004) Aspectos fisiológicos e de manejo para manutenção da homeostase térmica e controle de síndromes metabólicas. In: Mendes AA, Nääs IA, Macari M. Produção de Frangos de Corte: FACTA, p.137-155.

Mollenhorst H, Rodenburg TB, Brokkers EAM, Koene P, Boer IJM (2005) On-farm assessment of laying hen welfare: A comparison of one environment - Based and two animal-based methods. Applied Animal Behaviour Science 90:277-291.

Rostagno HS, Albino LFT, Donzele JL, Gomes PC, Oliveira RF, Lopes DC, Ferreira AS, Barreto SLT (2005) Tabelas brasileiras para aves e suínos: composição de alimentos e exigências nutricionais. Viçosa, MG: Universidade Federal de Viçosa, 186p.

Rudkin C, Stewart GD (2003) Behaviour of hens in cages - a pilot study using video tapes. A Report for the Rural Industries Research and Development Corporation 40:102.

Santos MJB, Pandorfi H, Almeida GLP, Morril WB, Pedrosa EMR, Guiselini C (2010) Comportamento bioclimático de frangos de corte caipira em piquetes enriquecidos. Revista Brasileira de Engenharia Agrícola e Ambiental 14:554-560.

SAS Institute, SAS (Statistical Analysis System). User's Guide. Cary, NC: SAS Institute Inc., 2003. 129p.

Souza BB, Lopes JJ, Roberto JVB, Silva AMA, Silva EMN, Silva GA (2010) Efeito do ambiente sobre as respostas fisiológicas de Caprinos Saanen e mestiços $1 / 2$ saanen $+1 / 2$ boer no semiárido Paraibano. Agropecuária Científica no Semiárido 6:47-51.

Sundrum A (2001) Organic livestock farming - a critical review. Livestock Production Science 67:207-215.

Takahashi AA, Mendes ESPB, Saldanha CC, Pizzolante K, Pelícia RG, Garcia ICLA, Paz RR (2006) Efeito do sistema de criação sobre o desempenho e rendimento de carcaça de frangos de corte tipo colonial. Arquivo Brassileiro de Medicina Veterinária e Zootecnia 58:624-632.

Tinôco IFF (2001) Avicultura industrial: novos conceitos de materiais, concepções e técnicas construtivas disponíveis para galpões avícolas brasileiros. Revista Brasileira de Ciência Avícola $3: 1-26$.

Veloso RC, Pires AV, Torres Filho RA, Pinheiro SRF, Winkelstroter LK, Alcântara DC, Cruz CCCS (2014) Parâmetros de desempenho e carcaça de genótipos de frangos tipo caipira. Arquivo Brasileiro de Medicina Veterinária e Zootecnia 66:1351-1359. 